\title{
Effects of low-level laser therapy on mast cell number and degranulation in third-degree burns of rats
}

\author{
Mohammad Bayat, PhD; ${ }^{1-2 *}$ Mohammad Mehdi Vasheghani, MSc; ${ }^{3}$ Naser Razavie, PhD; ${ }^{3}$ Mohammad Reza \\ Jalili, MD $^{2}$ \\ ${ }^{1}$ Cellular and Molecular Biology Research Center, ${ }^{2}$ Anatomy Department, Medical Faculty, and ${ }^{3}$ Paramedical Faculty, \\ Shahid Beheshti University, M.C., Tehran, Iran
}

\begin{abstract}
Mast cells have been shown to participate in the wound healing process. We investigated the effects of low-level laser therapy (LLLT) on mast cell number in the inflammation, proliferation, and remodeling phases of the wound healing process of experimental burns. Sixty rats subjected to third-degree burns were divided into four groups: two laser-treated, one control, and one nitrofurazone-treated group. In the two lasertreated groups, burned areas received LLLT with a helium-neon laser at energy densities of $38.2 \mathrm{~J} / \mathrm{cm}^{2}$ and $76.4 \mathrm{~J} / \mathrm{cm}^{2}$, respectively. The effects on mast cell number and degranulation were assessed 7, 16, and 30 days postburn (inflammation, proliferation, and remodeling phases of wound healing, respectively). Intact and degranulated mast cells were counted. Five rats with no burns were used for baseline studies. On day 7 in the first laser group, the total number of mast cells was significantly higher than in the other groups. On day 16 in the nitrofurazonetreated group, the total number of mast cells was significantly higher than in the control, first laser, and normal groups. LLLT on the experimental third-degree burns significantly increased the total number of mast cells during the inflammation phase of wound healing; also, topical application of $0.2 \%$ nitrofurazone ointment on the same burns significantly increased the total number of mast cells during the proliferation phase of burn healing.
\end{abstract}

Key words: burn, cell count, degranulation, helium-neon laser, histology, low-level laser therapy, mast cell, morphometry, rat, wound healing.

\section{INTRODUCTION}

The wound healing process is a normal physiological response to injury and generally leads to restoration of normal structure and function in damaged tissues. In certain disorders, the wound healing process leads to an altered restitution of tissue structure and function that is associated with the development of remodeling and fibrosis. Mast cells are related to the pathogenesis of many fibrotic disorders. However, mast cells have also been shown to participate in the wound healing process. The physiological role of mast cells in this process has been demonstrated in in vitro and in vivo wound healing models [1]. Wound healing is a complex process that involves the interaction of various cell types, such as lymphocytes, monocytes, epithelial cells, and fibroblasts. Three main overlapping phases have been identified in tissue response to injury: inflammation, formation of granulation tissue and matrix (proliferation), and

Abbreviations: ANOVA $=$ analysis of variance, $\mathrm{He}-\mathrm{Ne}=$ helium-neon, IGF-1 = insulin-like growth factor-1, LLLT = low-level laser therapy, LSD = least significant difference.

* Address all correspondence to Dr. Mohammad Bayat, Cellular and Molecular Biology Research Center, Medical Faculty, Shahid Beheshti University, M.C., PO Box 19395/ 4719, Tehran, Iran; 98-21-22400681.

Email: bayat m@yahoo.com

DOI: 10.1682/JRRD.2007.07.0110 
remodeling. During granulation tissue formation, fibroblasts proliferate and migrate into the wound space [2]. Levi-Schaffer and Kupietzky have demonstrated in vitro that mast cells influence the wound healing process by increasing fibroblast migration and proliferation [3]. This effect is partially mediated by histamine that acts on H2receptors on fibroblasts [4]. Besides histamine, interleukin4 derived from mast cells was also found to stimulate fibroblasts to proliferate and migrate [5]. New investigations are finding that skin mast cells modulate the inflammatory response in healing wounds [6], play a role in neoangiogenesis [7], and may participate in tissue remodeling in the late phase of wound healing [8]. Recent evidence has revealed that skin mast cells and mast cell chymase are important for the formation of granulation tissue and the synthesis of collagen fibers that occur at the edge of the wound in the burnhealing model in mice [9].

Thermal burns are less common than other forms of trauma, but they produce more severe physiological stresses than other forms of traumatic injuries. It is estimated that annually two million people suffer from burns in the United States [10].

Low-level laser therapy (LLLT) has become progressively more popular in the management of a wide variety of medical conditions, including the wound healing process [11]. In laboratory animals, biostimulation of wound healing results in faster healing of burns [12-14], stimulating effects on collagen synthesis in the wound, significant acceleration of wound contraction [15], improved tensile strength of the scar, an obvious increase in total collagen content of the wound [16], early epithelialization with increased fibroblastic reaction, considerable granulation tissue with noticeably higher collagen hydroxyproline concentration in scar tissue [17-18], dramatic decrease of inflammatory cells and also edema, obvious proliferation of myofibroblasts [19], and a greater mean quantity of collagen fibers both in diabetic and nondiabetic rats, as reported by several investigators [20].

Some in vitro studies also demonstrate stimulating effects of LLLT on the secretion of cytokines and growth factors from different cells and cell proliferation [21-25]. $\mathrm{Yu}$ et al. showed the positive effect of helium-neon (He$\mathrm{Ne}$ ) laser treatment on cytokine production in cultured keratinocytes [21]. The main finding of the study by Kipshidze et al. was that vascular endothelial growth factor is biologically active in human vascular smooth muscles, fibroblasts, and cardiac myocytes in vitro in response to laser treatment [22]. Vinck et al. reported that LLLT resulted in increased fibroblast proliferation in vitro [23]. In the Safavi et al. study, LLLT significantly increased gene expression of platelet-derived growth factor and transforming growth factor-beta [24]. The results of the Saygun et al. study showed that LLLT increased the proliferation of human gingival fibroblasts and increased the release of basic fibroblast growth factor, insulin-like growth factor-1 (IGF-1), and an IGF-1 receptor [25].

Few studies have been conducted regarding the effects of light on skin mast cells [26-27]. In their first study, El Sayed and Dyson showed that mast cells can be activated and their total number increased by treatment with certain wavelengths of light [26]. In their second study, El Sayed and Dyson showed that this increase in mast cell number is not pulse-frequency dependent, whereas degranulation is [27]. In a previous work, we showed that LLLT on deep second-degree cutaneous burns in rats significantly increases intact mast cells during the inflammation and proliferation phases of healing and decreases the total number of mast cells during the remodeling phase [28].

Until now, no knowledge has been available pertaining to the histological study of He-Ne laser treatment on mast cell morphometry in burned skin. The aim of the present study was to use a morphometrical method to evaluate the effect of LLLT with a He-Ne laser on the total number of mast cells and their degranulation in third-degree burns in rats.

\section{MATERIALS AND METHODS}

\section{Animals}

Sixty-five male adult Wistar rats weighing $250 \pm 30$ g, kept in separate cages, and fed ad libitum were used in this experiment. On day 0, 60 rats were anesthetized by intramuscular injection of $50 \mathrm{mg} / \mathrm{kg}$ ketamine hydrochloride and $5 \mathrm{mg} / \mathrm{kg}$ diazepam. The dorsal hair of the rats was shaved, and the skin was cleaned with povidone iodine. Rats were held in a special box with a $3 \times 3 \mathrm{~cm}$ opening. The back of each rat was exposed for $7 \mathrm{~s}$, via the opening, to the external lip of a $22 \mathrm{~mm}$-diameter cylinder that was connected to a source of boiling water. Histological examination showed that the epidermis and most of the dermis were burned. The surface area of burned skin was $3.8 \mathrm{~cm}^{2}$. All procedures were approved by the Institutional Medical Ethics Committee of Shahid Beheshti University, M.C. 


\section{Study Groups}

The animals were randomly divided into five groups. Rats in the control group ( $n=15)$ were left untreated. Rats in the two laser-treated groups ( $n=15$ each) were exposed daily to $38.2 \mathrm{~J} / \mathrm{cm}^{2}$ or $76.4 \mathrm{~J} / \mathrm{cm}^{2}$ LLLT, respectively, from day 1 after burning until the experimental time period was completed. The burned tissues daily received a certain amount of laser energy [12-14,29-31] during the wound healing process in order to increase reparative activities. The specifications of the laser (manufactured by Iranian Atomic Energy Agency; Tehran, Iran) are shown in the Table. To apply the laser treatment, we divided the burned area into several equal squares $(1 \times 1 \mathrm{~cm})$. The tip of the laser source was in light contact with the surface of the burned skin at the center of each square and directed perpendicularly to the target tissue for the designated time. For accurate LLLT, one formula was used for measurement of fluency (energy density) [32]:

$$
\text { Fluency } \left.\left(\mathrm{J} / \mathrm{cm}^{2}\right)=\text { [output }(\mathrm{mW}) \times \text { time }(\mathrm{s})\right] / \text { area }\left(\mathrm{cm}^{2}\right) \text {. }
$$

So, fluency of the first laser group $=0.010 \times 120$ / $0.0314=38.2 \mathrm{~J} / \mathrm{cm}^{2}$, and fluency of the second laser group $=0.010 \times 240 / 0.0314=76.4 \mathrm{~J} / \mathrm{cm}^{2}$. Irradiation was performed for $120 \mathrm{~s}$ for the first laser group and $240 \mathrm{~s}$ for the second laser group. The laser source output was controlled with a power meter. Rats in group four $(n=15)$ were treated daily with topical 0.2 percent nitrofurazone cream (Tehran Daru Co; Tehran, Iran) from day 1 after burning until the experimental time period was completed. Rats in each group were divided into three equal subgroups. After anesthesia with chloroform, subgroups a, b, and c were sacrificed by neck dislocation on days 7 , 16 , and 30 after burning, respectively. The fifth group, five rats with unburned skin, was used for baseline studies (“normal” group).

Table.

Specifications of low-level laser.

\begin{tabular}{ll}
\hline \multicolumn{1}{c}{ Laser Parameter } & \multicolumn{1}{c}{ Value } \\
\hline Laser Source & $10 \mathrm{~mW}$ Helium-Neon Laser Tube \\
Wavelength & $632.8 \mu \mathrm{m}$ \\
Frequency & Continuous \\
Spot Area & $3.14 \mathrm{~mm}^{2}$ \\
Application Time (daily) & First Laser Group $=120 \mathrm{~s}$, \\
& Second Laser Group $=240 \mathrm{~s}$ \\
\hline
\end{tabular}

\section{Morphometrical Examination}

Samples for histological examination were excised from the burned skin of each rat, fixed in buffered neutral formaline, and embedded in paraffin blocks. Then, sagittal sections were cut and stained with 1 percent toluidine blue in distilled water for 2 minutes until intact mast cells showed deep blue staining. On the basis of the degree of granulation, we can identify three types of mast cells, which represent different stages of mast cell degranulation in skin samples:

1. Intact dark blue cells.

2. Cells from which some granules have been extruded but with largely intact cell outlines.

3. Cells in which degranulation is more extensive and widespread, with complete or partial disintegration of the original cell outline [33].

After staining, we morphometrically examined 100 zones from each sample with a calibrated ocular on a light microscope at a magnification of $1000 \times$ with immersion oil. Morphometrical examination was performed by the procedure reported by Young and Dyson [34] with some modifications. Examination was performed in a blind fashion.

\section{Statistical Examination}

Data (between groups and within each group) were subjected to one-way analysis of variance (ANOVA). Data were expressed as mean \pm standard error of the mean. Multiple comparisons were performed with the least significant difference (LSD) test. We considered $p<$ 0.05 statistically significant.

\section{RESULTS}

Results of statistical analysis between groups are shown in Figures 1-3.

\section{Seven Days After Burning}

Type 1 mast cells in the first laser group were significantly higher than in the second laser and normal groups (LSD test: $p=0.04$ and $p=0.02$, respectively).

Type 2 mast cells in the first laser group were significantly higher than in the nitrofurazone-treated group (LSD test: $p=0.03$ ).

The total number of mast cells in the first laser group was significantly higher than in the second laser, nitrourazone-treated, control, and normal groups (LSD test: $p=0.02$ for all). 


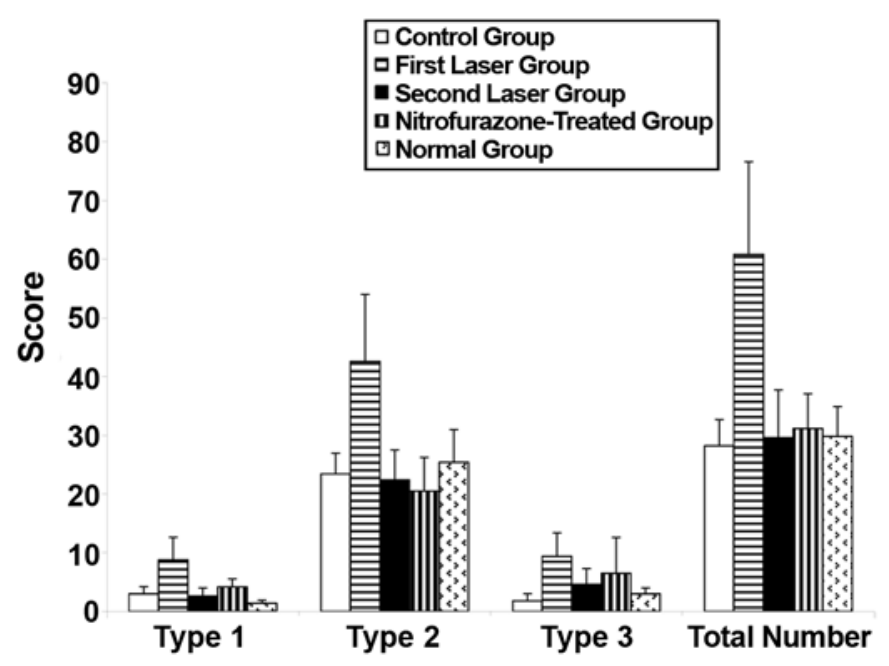

Figure 1.

Mean \pm standard error of the mean for types of mast cells and total number of them in 100 zones of burned skin in rats 7 days after burning. Analysis of variance showed that type 1 mast cells in first laser group were significantly higher than in second laser and normal groups (least significant difference [LSD] test: $p=0.04$ and $p=0.02$, respectively); type 2 mast cells in first laser group were significantly higher than in nitrofurazone-treated group (LSD test: $p=0.03$ ); and total number of mast cells in first laser group was significantly higher than in second laser, nitrofurazone-treated, control, and normal groups (LSD test: $p=0.02$ for all).

\section{Sixteen Days After Burning}

Type 1 mast cells in the nitrofurazone-treated group were higher than in the other groups; however, no significant differences were found between groups.

Type 2 mast cells in the nitrofurazone-treated group were significantly higher than in the control and normal groups (LSD test: $p=0.02$ and $p=0.01$, respectively).

Type 3 mast cells in the nitrofurazone-treated group were significantly higher than in the first laser and normal groups (LSD test: $p=0.04$ and $p=0.046$, respectively).

The total number of mast cells in the nitrofurazonetreated group was significantly higher than in the first laser, control, and normal groups (LSD test: $p=0.04, p=$ 0.01 , and $p=0.005$, respectively).

\section{Thirty Days After Burning}

Type 1 mast cells in the first laser group were higher than in the other groups; however, no significant differences were found between groups.

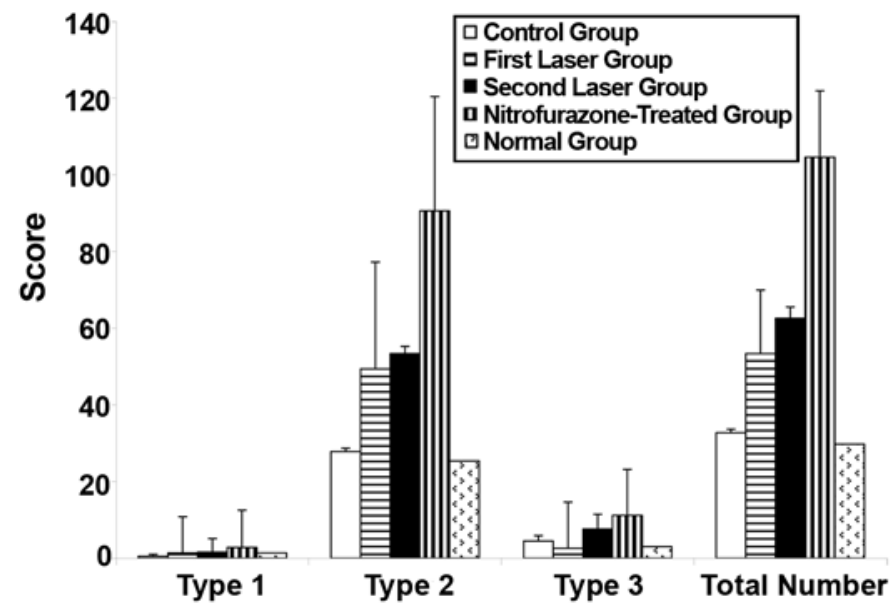

Figure 2.

Mean \pm standard error of the mean for types of mast cells and total number of them in 100 zones of burned skin in rats 16 days after burning. Analysis of variance showed that type 2 mast cells in nitrofurazone-treated group were significantly higher than in control and normal groups (least significant difference [LSD] test: $p=0.02$ and $p=0.01$, respectively); type 3 mast cells in nitrofurazone-treated group were significantly higher than in first laser and normal groups (LSD test: $p=0.04$ and $p=0.046$, respectively); and total number of mast cells in nitrofurazone-treated group was significantly higher than in first laser, control, and normal groups (LSD test: $p=0.04, p=0.01$, and $p=0.005$, respectively).

Type 2 mast cells in the nitrofurazone-treated group were significantly higher than in the normal group (LSD test: $p=0.04$ ).

Type 3 mast cells in the nitrofurazone-treated group were significantly higher than in the control and normal groups (LSD test: $p=0.01$ and $p=0.02$, respectively).

The total number of mast cells in the nitrofurazonetreated group was significantly higher than in the normal and control groups (LSD test: $p=0.02$ and $p=0.049$, respectively). The total number of mast cells in the second laser group was significantly higher than in the normal group (LSD test: $p=0.02$ ).

\section{Statistical Analysis Within Each Group}

\section{Second Laser Group}

Type 1 mast cells on day 30 were significantly higher than on days 7 and 16 (ANOVA test: $p=0.03$; LSD test: $p=0.03$ and $p=0.02$, respectively).

Type 2 mast cells on day 30 were significantly higher than on day 7 (ANOVA test: $p=0.11$; LSD test: $p=0.04$ ). 


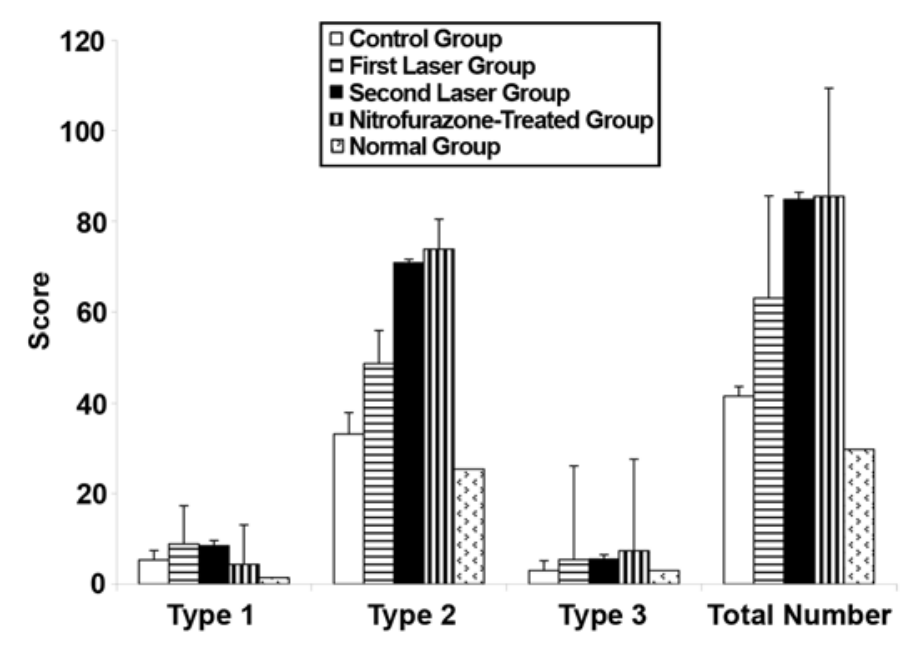

Figure 3.

Mean \pm standard error of the mean for types of mast cells and total number of them in 100 zones of burned skin in rats 30 days after burning. Analysis of variance showed that type 2 mast cells in nitrofurazone-treated group were significantly higher than in normal group (least significant difference [LSD] test: $p=0.04$ ); type 3 mast cells in nitrofurazone-treated group were significantly higher than in control and normal groups (LSD test: $p=0.01$ and $p=0.02$, respectively); and total number of mast cells in nitrofurazone-treated group was significantly higher than in normal and control groups (LSD test: $p=0.02$ and $p=0.049$, respectively). Total number of mast cells in second laser group was significantly higher than in normal group (LSD test: $p=0.02$ ).

The total number of mast cells on day 30 was significantly higher than on day 7 (ANOVA test: $p=0.07$; LSD test: $p=0.02$ ).

\section{Nitrofurazone-Treated Group}

Type 2 mast cells on day 7 were significantly lower than on days 16 and 30 (ANOVA test: $p=0.02$; LSD test: $p=0.01$ and $p=0.04$, respectively).

The total number of mast cells on day 7 was significantly lower than on days 16 and 30 (ANOVA test: $p=$ 0.02 ; LSD test: $p=0.01$ and $p=0.04$, respectively).

\section{DISCUSSION}

Mast cells may be important in wound healing because of their effects on collagen formation, vascular permeability, and angiogenesis. Experimental evidence for mast cell contribution to wound healing has largely been derived from the observation of altered mast cell numbers and his- tamine in rats undergoing wounding from incision [35]. LLLT, when used appropriately, can stimulate the healing of injured tissue such as the dermis [36]. Investigations into the mechanisms involved in the contribution of mast cells to wound healing, both in vitro and in vivo, have shown that different types of cells, whose interactions result in dermal repair, may receive a therapeutic advantage from treatment with LLLT [11].

Mast cells and macrophages can be stimulated to release growth factors and other substances, as the proliferation of fibroblasts, endothelial cells, and keratinocytes maintained in adverse conditions are stimulated. The development of granulation tissue is mainly controlled by growth factors released from macrophages [36].

Findings from the present study demonstrate that LLLT with an energy density of $38.2 \mathrm{~J} / \mathrm{cm}^{2}$ noticeably increased total number, type 1 , and type 2 mast cells during the inflammation phase of third-degree burn healing compared with control wounds and nitrofurazone-treated wounds. The findings in this study agree with others [26]. El Sayed and Dyson demonstrated considerably higher mast cell count and degranulation in partial-thickness wounds of male Wistar rats after $660 \mathrm{~nm}$ irradiation [26]. The biologically active substances released by mast cells stimulate tissue repair (including neovascularization) [37]. In another study, which was done under the same conditions, we found that LLLT with energy density of $38.2 \mathrm{~J} / \mathrm{cm}^{2}$ increased the number of blood vessels during the inflammation phase of third-degree burn healing [38]. These two findings have been observed to occur at the same time. Angiogenesis has an important role in wound healing [39]. Nienartowicz et al. showed that mast cells play a role in angiogenesis, both in normal conditions during tissue regeneration and in pathological neoplastic states [7].

Some authors have noted a close association between mast cells and angiogenesis in cancer, angiomas, lymphomas, and multiple myeloma [40-41]. Many biologically active substances contained in mast cell granules affect various stages of angiogenesis. For instance, tryptase (a novel potent angiogenic factor), in cooperation with heparin, stimulates migration and division of vascular endothelial cells [42]. Interleukin-8 increases the expression of the intercellular adhesion molecule- 1 protein that is present on the surface of endothelial cells and is responsible for cell adhesion during capillary formation [43]. Recently, Heissig et al. reported that low-dose 
irradiation fosters vascular-dependent regeneration of mast cells in the limb ischemia model. They concluded that increased recruitment and activation of mast cells following irradiation alter the ischemic microenvironment and promote vascular regeneration in an ischemic model [44]. Their results are consistent with those of the present study. LLLT seems to induce an increase in blood vessel sections during the inflammation phase of thirddegree burn healing through biologically active substances that are released by mast cells, which are significantly increased in number.

In the present study, we also found that topical application of nitrofurazone cream on the burned area considerably increased the total number of mast cells during the proliferation phase of burn healing compared with control and laser-treated burns. Also, it significantly increased the total number and type 2 mast cells on days 16 and 30 compared with day 7. In a previous study [38], we showed that nitrofurazone-treated burns noticeably increased the depth of new epidermis during the proliferation phase of burn healing, a significant finding considering the importance of epithelialization in wound covering. The positive effect of nitrofurazone cream on burn healing was also shown by the use of nitrofurazone-loaded synthetic dressings that extended to cover major portions of the burn, which reduced the required nursing care and lessened patient discomfort [45]. Herruzo-Cabrera et al. revealed that 0.2 percent nitrofurazone showed greater penetration strength in the scar compared with the weaker penetration of 0.5 and 1 percent chlorhexidine and the absence of penetration by the 1 percent silver sulphadiazine and 2.2 percent cerium nitrate [46]. Recently, several investigations have successfully used nitrofurazone cream as a standard topical agent on injured skin [47-49].

\section{CONCLUSIONS}

We conclude that LLLT on experimental third-degree burns significantly increased the total number of mast cells during the inflammation phase of burn healing and that topical application of 0.2 percent nitrofurazone ointment on the same burns significantly increased the total number of mast cells during the proliferation phase of burn healing.

\section{ACKNOWLEDGMENTS}

We wish to thank the late Mrs. Jamileh Rezaei. We also wish to thank the Vice Chancellor of Research at the Medical Faculty of Shahid Beheshti University, M.C., for financial support and Miss Nasrin Khateri for assisting with the figures.

This material was based on work supported by the Research Department in the Medical Faculty of Shahid Beheshti University, M.C. (grant 13266).

\section{REFERENCES}

1. Maurer M, Theoharides T, Granstein RD, Bischoff SC, Bienenstock J, Henz B, Kovanen P, Piliponsky AM, Kambe N, Vliagoftis H, Levi-Schaffer F, Metz M, Miyachi Y, Befus D, Forsythe P, Kitmura Y, Galli S. What is the physiological function of mast cells? Exp Dermatol. 2003; 12(6):886-910. [PMID: 14719507]

2. Clark RAF. Biology of dermal wound repair. Dermatol Clin. 1993;11:647-66.

3. Levi-Schaffer F, Kupietzky A. Mast cells enhance migration and proliferation of fibroblasts into an in vitro wound. Exp Cell Res. 1990;188(1):42-49. [PMID: 2328776]

4. Kupietzky A, Levi-Schaffer F. The role of mast cellderived histamine in the closure of an in vitro wound. Inflamm Res. 1996;45(4):176-180. [PMID: 8741007]

5. Trautmann A, Toksoy A, Engelhardt E, Bröcker E, Gillitzer R. Mast cell involvement in normal human skin wound healing: expression of monocyte chemoattractant protein-1 is correlated with recruitment of mast cells which synthesize interleukin-4 in vivo. J Pathol. 2000;190(1):100-6.

6. Martin P, Leibovich SJ. Inflammatory cells during wound repair: The good, the bad and the ugly. Trends Cell Biol. 2005;15(11):599-607. [PMID: 16202600]

7. Nienartowicz A, Sobaniec-Lotowska ME, Jarocka-Cytra E, Lemancewicz D. Mast cells in neoangiogenesis. Med Sci Monit. 2006;12(3):RA53-56. [PMID: 16501434]

8. Iba Y, Shibata A, Kato M, Masukawa T. Possible involvement of mast cells in collagen remodeling in the late phase of cutaneous wound healing in mice. Int Immunopharmacol. 2004;4(14):1873-80. [PMID: 15531302]

9. Nishikori Y, Kakizoe E, Kobayashi Y, Shimoura K, Okunishi H, Dekio S. Skin mast cell promotion of matrix remodeling in burn wound healing in mice: Relevance of chymase. Arch Dermatol Res. 1998;290(10):553-60. [PMID: 9836506]

10. Barillo DJ, McManus AT. Infections in burn patients. In: Armstrong D, Cohen J, editors. Infectious disease. London: Mosby; 1999. p. 8.1-8.8. 
11. Hawkins D, Houreld N, Abrahamse H. Low level laser therapy (LLLT) as an effective therapeutic modality for delayed wound healing. Ann N Y Acad Sci. 2005;1056: 486-93. [PMID: 16387711]

12. Mester E, Spiry T, Szende B, Tota JG. Effect of laser rays on wound healing. Am J Surg. 1971;122(4):532-35.

[PMID: 5098661$]$

13. Rochkind S, Rousso M, Nissan M, Villarreal M, Barr-Nea L, Rees DG. Systemic effects of low-power laser irradiation on the peripheral and central nervous system, cutaneous wounds, and burns. Lasers Surg Med. 1989;9(2):174-82. [PMID: 2716462]

14. Ribeiro MS, Da Silva Dde F, De Araújo CE, De Oliveira SF, Pelegrini CM, Zorn TM, Zezell DM. Effects of lowintensity polarized visible laser radiation on skin burns: A light microscopy study. J Clin Laser Med Surg. 2004;22(1): 59-66. [PMID: 15117489]

15. Kana JS, Hutschenreiter G, Haina D, Waidelich W. Effect of low-power density laser radiation on healing of open skin wounds in rats. Arch Surg. 1981;116(3):293-96. [PMID: 7469766]

16. Lyons RF, Abergel RP, White RA, Dwyer RM, Castel JC, Uitto J. Biostimulation of wound healing in vivo by a helium-neon laser. Ann Plast Surg. 1987;18:47-50. [PMID: 3827131$]$

17. Mester E, Jaszsagi-Nagi E. The effect of laser radiation on wound healing and collagen synthesis. Studia Biophys. 1971;35:227-30.

18. Bisht D, Gupta SC, Mirsa VL, Mital VP, Sharma P. Effect of low intensity laser radiation on healing of open skin wounds in rats. Indian J Med Res. 1994;100:43-46. [PMID: 7927552]

19. Medrado AR, Pugliese LS, Reis SR, Andrade ZA. Influence of low level laser therapy on wound healing and its biological action upon myofibroblasts. Lasers Surg Med. 2003;32(3):239-44. [PMID: 12605432]

20. Carvalho PT, Mazzer N, Dos Reis FA, Belchior AC, Silva IS. Analysis of the influence of low-power HeNe laser on the healing of skin wounds in diabetic and nondiabetic rats. Acta Cir Bras. 2006;21:177-83.

21. Yu HS, Chang KL, Yu CL, Chen JW, Chen GS. Low-energy helium-neon laser irradiation stimulates interleukin-1 alpha and interleukin-8 release from cultured human keratinocytes. J Invest Dermatol. 1996;107:593-96. [PMID: 8823366]

22. Kipshidze N, Nikolaychik V, Keelan MH, Shankar LR, Khanna A, Kornowski R, Leon M, Moses J. Low-power helium:neon laser irradiation enhances production of vascular endothelial growth factor and promotes growth of endothelial cells in vitro. Lasers Surg Med. 2001;28(4): 355-64. [PMID: 11344517]

23. Vinck EM, Cagnie BJ, Cornelissen MJ, Declercq HA, Cambier DC. Increased fibroblast proliferation induced by light emitting diode and low power laser irradiation. Lasers Med Sci. 2003;18(2):95-99. [PMID: 12928819]

24. Safavi SM, Kazemi B, Esmaeili M, Fallah A, Modarresi A, Mir M. Effects of low-level He-Ne laser irradiation on the gene expression of IL-1 beta, TNF-alpha, IFN-gamma, TGF-beta, bFGF, and PDGF in rat's gingiva. Lasers Med Sci. 2008;23(3):331-35. [PMID: 17786499]

25. Saygun I, Karacay S, Serdar M, Ural AU, Sencimen M, Kurtis B. Effects of laser irradiation on the release of basic fibroblast growth factor (bFGF), insulin like growth factor-1 (IGF-1), and receptor of IGF-1 (IGFBP3) from gingival fibroblasts. Lasers Med Sci. 2008;23(2):211-15.

[PMID: 17619941]

26. El Sayed SO, Dyson M. Comparison of the effect of multiwavelength light produced by a cluster of semiconductor diodes and of each individual diode on mast cell number and degranulation in intact and injured skin. Lasers Surg Med. 1990;10(6):559-68. [PMID: 2263155]

27. El Sayed SO, Dyson M. Effect of laser pulse repetition rate and pulse duration on mast cell number and degranulation. Lasers Surg Med. 1996;19(4):433-37. [PMID: 8983003]

28. Vasheghani MM, Bayat M, Rezaei F, Bayat A. Effect of low-level laser therapy on mast cells in deep second-degree burns of rats. Photomed Laser Surg. 2008;26(1):1-5. [PMID: 18248153]

29. Cambier DC, Vanderstraeten GG, Mussen MJ, Van der Spank JT. Low-power laser and healing of burns: A preliminary assay. Plast Reconstr Surg. 1996;97(3):555-58. [PMID: 8596786]

30. Schlager A, Oehler K, Huebner KU, Schmuth M, Spoetl L. Healing of burns after treatment with 670-nanometer lowpower laser light. Plast Reconstr Surg. 2000;105(5):1635-39. [PMID: 10809091]

31. Schlager A, Kronberger P, Petschke F, Ulmer H. Lowpower laser light in the healing of burns: A comparison between two different wavelengths (635 and $690 \mathrm{~nm}$ ) and a placebo group. Lasers Surg Med. 2000;27(1):39-42. [PMID: 10918291]

32. Tuner J, Hode L. Laser therapy clinical practice and scientific background. Grängesberg (Sweden): Prima Books; 2002. p. 328.

33. Dyson M, Lake DA. Induction of mast cell degranulation in skin by ultrasound. IEEE Trans Ultrason Ferroelectr Freq Control. 1986;33(2):194-201

34. Young SR, Dyson M. Effect of therapeutic ultrasound on healing of full thickness excised skin lesion. Ultrasonic. 1990;28:175-80. [PMID: 10918291]

35. Rothe MJ, Nowak M, Kerdel FA.The mast cell in health and diseases. J Am Acad Dematol. 1990; 23: 615-624.

36. Mati M, Lazeti B, Poljacki M, Duran V, Ivkov-Simi M. [Low-level laser irradiation and its effect on repair 
processes in the skin]. Med Pregl. 2003;56(3-4):137-41. Croatian. [PMID: 12899077]

37. Brem H, Klagsburn M. The role of fibroblast growth factors and related oncogenes in tumor growth. Cancer Treat Res. 1992;63:211-231. [PMID: 1284026]

38. Bayat M, Vasheghani MM, Razavi N. Effect of low-level helium-neon laser therapy on the healing of third-degree burns in rats. J Photochem Photobiol B. 2006;83(2):87-93. [PMID: 16455266]

39. Clark RAF. Mechanism of cutaneous wound repair. In: Fitzpatrick TB, Elsen AZ, Wolf K, editors. Dermatology in general medicine. Philadelphia: McGraw-Hill; 1993. p. 473-85.

40. Norrby K, Woolley D. Role of mast cells in mitogenesis and angiogenesis in normal tissue and tumor tissue. Advanc Biosci. 1993;89:71-115.

41. Ribatti D, Vacca A, Marzullo A, Nico B, Ria R, Roncali L, Dammacco F. Angiogenesis and mast cell density with tryptase activity increase simultaneously with pathological progression in B-cell non-Hodgkin's lymphomas. Int J Cancer. 2000;85(2):171-175. [PMID: 10629073]

42. Blair RJ, Meng H, Marchese MJ, Ren S, Schwartz LB, Tonnesen MG, Gruber BL. Human mast cells stimulate vascular tube formation. Tryptase is a novel, potent angiogenic factor. J Clin Invest. 1997;99(11):2691-2700. [PMID: 9169499$]$

43. Grützkau A, Krüger-Krasagakes S, Kögel H, Möller A, Lippert U, Henz BM. Detection of intracellular interleukin-8 in human mast cells: Flow cytometry as a guide for immunoelectron microscopy. J Histochem Cytochem. 1997;45(7): 935-45. [PMID: 9212819]
44. Heissig B, Rafii S, Akiyama H, Ohki Y, Sato Y, Rafael T, Zhu Z, Hicklin DJ, Okumura K, Ogawa H, Werb Z, Hattori $\mathrm{K}$. Low-dose irradiation promotes tissue revascularization through VEGF release from mast cells and MMP-9-mediated progenitor cell mobilization. J Exp Med 2005;202(6): 739-50. [PMID: 16157686]

45. Nathan P, Robb EC, Law EJ, MacMillan BG. A clinical study of antimicrobial agents delivered to burn wounds from a drug-loaded synthetic dressing. J Trauma. 1982; 22(12):1015-18. [PMID: 7143507]

46. Herruzo-Cabrera R, Garcia-Torres V, Rey-Calero J, VizcainoAlcaide MJ. Evaluation of the penetration strength, bactericidal efficacy and spectrum of action of several antimicrobial creams against isolated microorganisms in a burn centre. Burns. 1992;18(1):39-44. [PMID: 1558672]

47. Mukherjee PK, Suresh B. The evaluation of wound-healing potential of Hypericum hookerianum leaf and stem extracts. J Altern Complement Med. 2000;6(1):61-69. [PMID: 10706238]

48. Mukherjee PK, Verpoorte R, Suresh B. Evaluation of invivo wound healing activity of Hypericum patulum (Family: hypericaceae) leaf extract on different wound model in rats. J Ethnopharmacol. 2000;70(3):315-21. [PMID: 10837993]

49. Mukherjee PK, Mukherjee K, Rajesh Kumar M, Pal M, Saha BP. Evaluation of wound healing activity of some herbal formulations. Phytother Res. 2003;17(3):265-68. [PMID: 12672158]

Submitted for publication July 22, 2007. Accepted in revised form January 16, 2008. 